\title{
Sir Asutosh and Rise of Modern Science in India
}

\author{
Kankan Bhattacharyya*
}

(Received 18 June 2014)

\begin{abstract}
Sir Asutosh Mookerjee is one of greatest educationist ever born in India. He was an outstanding mathematician and the first Indian to publish a scientific paper in a Journal. Due to lack of opportunity he 'drifted to law.' He was Vice Chancellor of the Calcutta University for ten years (1906-1914, 1921-23). As a Vice chancellor, he collected a galaxy of professors - Brajen Seal, C V Raman, S Radhakrishnan, S N Bose, M N Saha, J C Ghosh, Agarkar, Ganesh Prasad, S K Banerjee and others. In 1914, he founded the Science College of Calcutta University. The same year he presided over the first session of the Indian Science Congress.
\end{abstract}

Key words: Calcutta University, Educationist, Judge, Lawyer, Mathematician, Nationalist, Science College, Science Congress, Sir Asutosh Mookerjee, Vice-chancellor.

\section{INTRODUCTION}

Sir Asutosh Mookerjee (29 June 1864 25 May 1924) is considered to be the harbinger of modern science in India (Fig. 1). He was the first Indian to initiate research in modern science, first

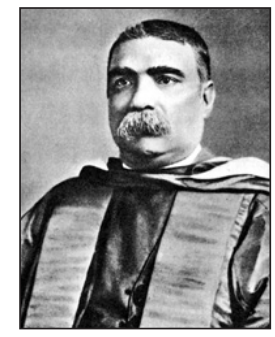

Fig. 1. Asutosh Mookerjee (18641924) Indian to publish a paper in a Journal and was arguably, the most illustrious figure in Indian education. He was the second Indian Vice Chancellor (VC) of the Calcutta University and occupied the post for ten years (1906-1914) and (1921-23). As a Vice chancellor, he collected a galaxy of Professors - Brajen Seal, C V Raman, S Radhakrishnan, S N Bose, M N Saha, J C Ghosh, Agarkar, Ganesh Prasad, S K Banerjee and others. He was the founder of the Science College of Calcutta University. He was president of the first session of the Indian Science Congress (1914) and the main architect of science education and research, in modern India.

\section{INDIAN RENAISSANCE}

The Indian Renaissance was led by Raja Rammohon (1772-1833). On 11 December 1823, in a historic letter to Lord Amherst, Rammohan requested the British government to "promote mathematics, natural philosophy (physics), chemistry, anatomy and other useful sciences." The British Government completely ignored this letter. About 10 years later, in 1835, Lord Macaulay in his famous Minutes reiterated the need for introducing western education in India and observed,

\section{"Having become educated in European Knowledge, India may demand European institutions. That will be the proudest day in English history."}

P C Ray commented "We do not know which of the two to admire most - Rammohan or Macaulay” for introducing western education in India (Ray, 1902). The science movement started by Rammohan was carried further by Derozio (1809-1831) Vidyasagar (1820-1891), M L Sircar (1833-1903), Bankimchandra (18331886) and J N Tata (1839-1904).

\footnotetext{
* Department of Physical Chemistry, Indian Association for the Cultivation of Science, Jadavpur, Kolkata 700032 , India. e-mail: pckb@iacs.res.in
} 
The First War of Independence (Sipahi Mutinee) in 1857, stirred all sections of Indian society and forced the British Government to take some positive steps. In 1855, the government took over Hindu College (founded in 1817) and named it Presidency College and started teaching of science subjects there. This was demanded by Rammohon and others long ago. The first Indian Universities (Calcutta, Bombay and Madras) were created in 1857. These events accelerated the Indian Renaissance. In 1876, Dr. M L Sircar (18331903), a medical doctor, founded Indian Association for the Cultivation of Science (IACS) at 210 Bowbazar Street as a "solely native and purely national” research institute (Biswas, 2001, 2003).

\section{EARLy Life \& Education}

Sir Asutosh Mookerjee was born on June 29, 1864, in the progressive environment unleashed by the Sipahi Mutiny. Many luminaries of modern India, were Asutosh's contemporaries. They include, Bal Gangadhar Tilak (1856-1920), J C Bose (1858-1937), Tagore (1861-1939), P C Ray (1861-1944), Vivekananda (1863-1902), Madan Mohan Malaviya (1861-1946), Lal Lajpat Rai (1865-1928) and Gandhi-ji (1869-1948). Asutosh met Vidyasgar when he was young. This meeting deeply inspired him and left a life-long impression on him.

Asutosh was born at Bowbazar, very close to IACS. His father Ganga Prasad Mookerjee, a well- known doctor, founded the South Suburban School at Calcutta. He brought up Asutosh in an enlightened atmosphere of science and literature at home. Thus the idealism for education and institute building was already in their family.

Asutosh had a deep love and respect for his mother, Jagattarani Devi. Asutosh never went abroad because his mother, would not allow her son to cross the seas (kalāpān $\bar{\imath}$ ). Once Lord Curzon (who was impressed by Ashutosh's scholarship) wanted him to go to England. Curzon ordered
Asutosh, "Tell your mother the Viceroy and Governor-General of India commands her son to go.” Defying Curzon's order, Asutosh replied: "Then I will tell the Viceroy and Governor-General of India that Asutosh Mookerjee refuses to be commanded by any other person except his mother, be he Viceroy or be he somebody higher still." This fearlessness in his character earned him the name Tiger of Bengal. The Jagattarani Medal of Calcutta University is named after Asutosh's mother.

In 1879, at the age of fifteen, Asutosh passed the entrance exam of the Calcutta University ranking third in the University. He took admission at the Presidency College where he met P C Ray and Narendranath Dutta (Vivekananda). In 1883, he stood first in the BA examination at Calcutta University and was awarded the Premchand-Roychand scholarship to complete a postgraduate degree in mathematics. In 1885, he completed MA in Mathematics and in 1886, MA in Physical Science. He was the first person to be awarded a dual MA degree from Calcutta University.

\section{Research in Mathematics}

Asutosh started doing original research in mathematics while he was studying BA. In his first paper, he gave a new proof of the 25th proposition of Euclid's first book. He was the First Indian to publish a paper in a Journal. Though he was busy in getting two MA degrees, Asutosh managed to publish 16 papers and 3 mathematical notes between 1883-1892 (see. Table 1) (Sengupta, 2000). His third paper on elliptic functions attracted praise from Prof. Cailey of Cambridge. His other areas of interest were differential equations of conics and hydrokinetic (hydrodynamic) phenomena.

When Asutosh published his first paper, Ramanujan (1887-1921) and Raman (1888-1970) were not even born. In the 1880-s, Calcutta University had no department or center for post- 
graduate teaching and research. It was merely a degree giving body. Post-graduate teaching used to be carried out only at Presidency College. Asutosh was not eligible to get a job at Presidency College because he did not have a foreign degree. The first two Indian professors at Presidency College J C Bose and P C ray were appointed in 1885 and in 1889, respectively, after they returned with a doctorate degree from England.

From 1887, at the invitation of M L Sircar, Asutosh started giving courses on Mathematics and Mathematical Physics at IACS. He delivered 12 lectures in 1887 . His lectures were appreciated in the annual report of IACS as follows,

\begin{abstract}
"Two new subjects were lectured uponMathematics and Geology. The lectures on Mathematics were of a superior order and have been embodied in a memoir by the lecturer Asutosh Mookerjee, published in the Journal of the Asiatic Society of Bengal.”
\end{abstract}

Asutosh delivered 20 lectures in 1888. In 1889, he gave 24 lectures in Mathematical Physics and 20 in pure Mathematics. This was followed by 20 lectures in 1890 . During this period, he was also practicing at Calcutta High Court as a lawyer. By 1893, he was elected as a Fellow of the Royal Society of Edinburgh, of the Societe de Physique of France and the Royal Irish Academy. His aim was to be a professor of mathematics at the Calcutta University. Sir Gooroodas Banerjee, the first Indian VC of Calcutta University, tried to create a post for Asutosh but could not collect enough money. After 1890, Asutosh stopped giving lectures at IACS and permanently shifted to law. About this Asutosh wrote,

\begin{abstract}
"I began my life as a research student in Mathematics, when research was practically unknown in this country. I hoped that the mission of my life was to be a Research Professor. The then ViceChancellor failed to collect even Rs. 4000 a year to maintain me as a research Professor. I drifted to law but I made a determination that I would devote myself to the service of the University so that in the next generation any aspiring scholars might have adequate opportunities to devote into the cause of science."
\end{abstract}

Asutosh took a Law degree from the City College, Calcutta, and won the 'Tagore Law Gold

Table 1. List of Papers Published by Asutosh on Mathematics

1. Proof of Euclid I, 25. Messenger in Math., 210 (1883):122-123.

2. Extension of a theorem of Salmon's. Messenger in Math., 213(1883-84):157-160.

3. A note on elliptic functions. J. Pure Appl. Math. 21 (1886):212-217.

4. On the differential equation of a trajectory. J. Asiatic Soc. Bengal, 56 (1887):117-120.

5. On Monge’s differential equation to all conics. J. Asiatic Soc. Bengal, 56 (1887):134-135.

6. A memoir on plane analytical geometry. J. Asiatic Soc. Bengal. 56(1887):288-349.

7. A general theorem on differential equations of trajectories. J. Asiatic Soc. Bengal, 57 (1888):72-99.

8. On Poisson's Integral. J. Asia Soc. Bengal, 57 (1888):100-106.

9. On the differential equations of all parabolas. J. Asia Soc. Bengal 57 (1888):316-332.

10. Remarks on Monge’s differential equation to all conics. Proc. Asia Soc. Bengal, Feb 1888.

11. The geometric interpretation of Monge's differential equation to all conics. J. Asia Soc. Bengal 58 (1889): 181-185.

12. Some applications of elliptic functions: First paper. J. Asia. Soc. Bengal, 58 (1889):199-213.

13. Some applications of elliptic functions: Second paper. J. Asia.Soc. Bengal, 58 (1889) :213-231.

14. On Clebsch's transformation of the hydrokinetic equations. J. Asia. Soc. Bengal, 59 (1890):56-59.

15. Note on Stoke's Theorem and hydrokinetic circulation. J. Asia. Soc. Bengal, 59 (1890) :59-61.

16. In a curve of aberrancy. J. Asia. Soc. Bengal, 59 (1890):61-63.

17. Mathematical notes (Questions\& solutions). Educational Times, London 43 (1890-92): 125-151; 44, 144-182; 45, 146-168. 
Medal' for three successive years: 1884, 1885 and 1886. In 1888, Ashutosh started practicing as an Advocate at the Calcutta High Court.

That Asutosh had to leave mathematics and to take law as profession deeply saddened M L Sircar. In the annual meeting of IACS, held on $16^{\text {th }}$ May 1893, Sircar lamented,

\begin{abstract}
"It breaks my heart to see what fine and splendid intellects are being wasted. Our own University has turned out a graduate (Asutosh) who is a genius in Mathematics. But he must earn his bread by other means than Mathematics and we have a sad spectacle of this brilliant genius wasting his energies within the granite walls of High Court.”
\end{abstract}

\section{Drift to LaW AND EARLY PERIOD OF association with Calcutta University}

Asutosh's brilliance was noted by the authorities of Calcutta University. He was elected as a Fellow and member of the syndicate Calcutta University when he was barely 25. Though he gradually drifted to law, Asutosh was President of the Board of studies in Mathematics for 11 years. From 1899 to 1903, Asutosh represented the Calcutta University in the Bengal Council. In 1904, Asutosh was appointed as a Judge of Calcutta High Court. In the following two years (1904-06) he delivered nearly 2000 judgments. His judgments, both in terms of quality and numbers, are regarded as master piece of judicial wisdom, till today. His persuasive power, erudition and knowledge of law made him eminently qualified him for the post of VC. Before describing his stint as VC, we will digress a little to describe the prevailing socio-political situation.

\section{Partition of Bengal, National Council of Education and Bengal Technical Institute}

By early 1900, the freedom movement in India gathered enough momentum. The Congress party, founded in 1885, aroused the aspirations of an emerging nation. Lal-Bal-Pal (Lala Lajpat Rai, Bepin Behary Pal and Bal Gangadhar Tilak) articulated the need for Swarāj (freedom). The British Government adopted several tactics to weaken the movement.

The shrewd British government understood that the universities and educational institutes serve as the think-tank of political movements and are a powerful platform for forming public opinions. Thus the government decided to create a vice-like grip on the universities. A secret circular of the Home department advised Lord Curzon that "We must have a working majority in favor of our views." Accordingly, the government passed the Universities Act of 1904. The new act ensured more white members in the Senate and Syndicate of the Universities. This act gave sweeping power to the government to appoint Vice Chancellor (VC) and all faculties and also for cancelling any appointment. The Government was empowered to affiliate and disaffiliate private colleges. This was intended to disaffiliate those colleges which were regarded as hot beds of nationalist agitation. Asutosh and Gokhale opposed this draconian act.

The second and more ugly tactics was the divide and rule policy which tried to create a rift between Hindu and Muslim Communities. In July 1905, Lord Curzon, Governor-General of India, announced the decision to divide Bengal into two parts on the basis of religion- the Hindu Dominated West Bengal and Muslim dominated East Bengal. The two communities immediately decided to fight this and launched an anti-partition movement. Tagore wrote a famous song for the anti-partition movement (Bānglār Mātū, Bānglār Jal).

The intellectuals, who were unhappy about the lack of facility for post-graduate teaching in Calcutta University became totally disgusted with the Calcutta University. After the 1904, they 
started calling Calcutta University as "Goldighir Ghulāmkhānā" (the slave house of Goldighi i.e. the pond opposite Calcutta University). Another sore point was the Indian Languages. Around 1886, C R Das, Asutosh and Bankim Chandra urged the Calcutta University to introduce Indian languages (Bengali, Urdu and Hindi) as subjects in the syllabi and examinations of the University. Though Sir Gooroodas, the then VC, was highly in favor of this, he could not get it passed by the University senate and syndicate. As a result, a section of the Indian intellectuals in India started campaigning for a separate national university. They were convinced about the power of knowledge in science and technology and were inspired by the fact that in 1905, a small country Japan defeated the mighty Russian empire, just through better education (Ray, 1902).

Several meetings were organized in 1905 to set up a national University. On 9 November 1905, at a meeting held at the Field and Academic Club, Subodh Chandra Mullick pledged Rupees one lakh for the foundation of a National University "under national control”. Generous sums of money were also donated by Brojendra Kishore Roy Choudhury, Maharaja Suryya Kanto Acharya Choudhury and Rasbehary Ghosh. Ghosh, a renowned lawyer and past President of Congress Party, was appointed the first president of the University. Within one week another meeting was organized by the Landholders Society on 16 November 1905, at Park Street. This meeting was attended by 1500 delegates, including Rabindranath Tagore, Aurobindo Ghosh, Raja Subodh Chandra Mullick and Brajendra Kishore Roychowdhury. In this meeting, the national university was proposed to be named as the National Council of Education (NCE). Aurobindo left his job at MS University, Baroda and joined NCE as honorary professor. NCE suffered a severe jolt in 1908 when Aurobindo, a freedom fighter, got arrested in the Alipur Bomb Case.
Almost on the same day that the National Council of Education was set up, another group took initiative to set up an engineering college. Sir Taraknath Palit, an eminent lawyer, founded the Society for Promotion of Technical Education (SPTE) in Bengal. This society started an engineering college, the Bengal Technical Institute which started operating on July 25, 1906 from Palit's residence at 92, Upper Circular Road (now APC Ray Road) at Kolkata. In the initial years, the NCE and SPTE fought with each other. In 1910, SPTE merged with the NCE.

P N Bose (1855-1934), an eminent geologist, joined Bengal Technical Institute as honorary Principal (Radhakrishna, 1997). Bose went to England in 1874, a few years before J C Bose and P C Ray. In the graduation examination of London University in 1877, P N Bose secured third rank in Geology and joined Royal School of Mines. He was actively involved in politics and was against the British Government. He was sent back to India in 1880 with a job in the Geological Survey of India. At the Survey, Bose eventually became the senior-most officer and was all set to become its first Indian Director in 1903. However, the British government refused to allow an Indian to head the Survey and appointed an officer, junior to Bose, to this post. As a protest, Bose resigned from the survey in 1903. Immediately after resignation, he joined the Mayurbhanj state as its state geologist. During his assignment at Mayurbhanj, he discovered the rich iron-ore deposit at Singhbhum district and convinced J N Tata to set up the TISCO factory at Tatanagar.

\section{Vice Chancellorship}

In 1906, when the anti-partition movement was at its peak, the British Government appointed Asutosh as the VC of Calcutta University as a damage control exercise to restore the faith of the Indians on the Calcutta University. Recommending Asutosh for the post of VC, the Home Secretary H H Risely wrote, 
The appointment of a distinguished Indian (Asutosh) as VC would undoubtedly be popular and would tend in some degree to discourage the idea that the sole purpose of the University act (of 1904) was to tighten official control over the Universities.

Lord Minto, the new Viceroy, allowed Asutosh to make several changes which increased respect for both Asutosh and the University. At that time Bamflyde Fuller, the LieutenantGovernor of Bengal and Assam, recommended disaffiliation of all the schools whose students participated in the anti-partition movement (M N Saha was expelled from one of these schools for taking part in the anti-partition movement). Asutosh argued that such a move will be highly counter- productive. Lord Minto agreed with Asutosh. This made Fuller very unhappy and he resigned.

As VC, Asutosh started transforming Calcutta University from a body, conducting examination and awarding degree, to a center of learning and research. One of his major triumphs was to convince the Senate and Syndicate to "accord due recognitions to Indian vernaculars." He introduced Bengali, Hindi, and Urdu (and eventually Sanskrit and Pali) as subjects in Calcutta University. This is acknowledged in the following write-up, engraved below his marble bust at the Asutosh Museum of Arts at the Calcutta University,

\section{'His noblest achievement, surest of them all, a place for his mother tongue - in step- mother's hall.'}

The British government honored Asutosh with a Companion of the Order of the Star of India (CSI) in June 1909. He was knighted in 1911 for his contributions to education in India. In 1911, Asutosh created the Chair of King George V Professor of Mental and Moral Science and invited Sir Brajendranath Seal as its first occupant. Sir B N Seal had applied genetic method in the field of aesthetics and also was an international founder of statistics. After Brajendratnath moved to Mysore University as Vice-chancellor in 1921, Asutosh invited Radhakrishnan, who was then at Mysore University, as Brajendranath's successor in the same chair.

\section{The Science College}

Within a few years after Asutosh became VC, there were several important developments in the sphere of science education and research in Calcutta. We have discussed earlier the establishment of National Council of Education and Bengal Technical Institute. In 1907, C V Raman came to Kolkata to work as the Assistant Auditor General to the Government of India. Very soon he discovered IACS and started doing research there outside his office hours. Raman published a short paper in Nature within a few months after coming to Kolkata. In the annual meeting of IACS, held on 21 November 1907, A L Sircar (son of M L Sircar) introduced Raman as 'a young man of fine intellect' and announced,

\begin{abstract}
A side issue of his work has been published in Nature. The prophecy of the great man (M L Sircar) is now going to be fulfilled. If circumstances do not go against us Raman will be the brightest ornament of our association (IACS).
\end{abstract}

Raman's arrival made a stupendous impact on the scientific research in India.

In 1908, Asutosh founded the Calcutta Mathematical Society and served as its President from 1908 to 1923.

By 1912, T N Palit’s (1831-1914) relation with National Council of Education (NCE) deteriorated. Palit was getting very old and was desperate to see that a center for higher studies in science (Science College) comes up before his death. Asutosh had already earned faith and trust from all quarters. Palit severed his relation with NCE and ordered Bengal Technical Institute to leave the premises at 92, Upper Circular Road. The orphaned Bengal Technical Institute started 
operating from rented houses as a private engineering college and eventually in 1955, became the Jadavpur University through the initiative of Triguna Sen.

In 1912, T N Palit donated Rs. 1.5 million (15 lakh) and in 1912 Rashbehari Ghosh (18451921, who was still President of NCE) donated Rs. 1 million for the Science College. Palit further donated his two houses- one at 92, Upper Circular Road and one at 35, Ballygunge Circular Road. On 27 March 1914, Asutosh laid the foundation stone of the Science College. Thus before Palit died on 3 October 1914, he could see the birth of the Science College.

The British Government was very skeptical about the Science College. Their main fear was that the Science College may be a hub of the terrorists who might use the laboratories for making bombs. The government did not provide any grant for Science College and even boycotted the foundation ceremony. Four days after the laying of the foundation of Science College Asutosh's $4^{\text {th }}$ two-year term as VC expired. He was not given any extension. But being a shrewd lawyer, Asutosh already made such an arrangement that he would remain the chairman of Palit Trust and as such had full control on the appointment and other affairs of Science College.

Asutosh now set about recruiting faculty for the Science College. The condition of the Palit trust was that the faculty must be Indian in origin but the person must have foreign training. P C Ray accepted the post of Palit Professor in Chemistry. Ray retired from Presidency College and lived on the pensions he earned. He donated his entire salary as Palit Professor to the Calcutta University. $\mathrm{J}$ C Bose was not available because he was planning to establish Bose Institute (founded in 1917) after retirement from Presidency College.

Asutosh selected Raman for the post of Palit Professor of Physics. Ganesh Prasad and Agarkar were appointed as Professors in
Mathematics and Botany. About Raman's selection, Asutosh said in the syndicate,

\begin{abstract}
"for the chair of Physics created by Sir TN Palit, we have been fortunate enough to secure the services of Mr. C V Raman who has greatly distinguished himself and acquired a European fame by his brilliant researches in the domain of physical sciences, assiduously carried on, under the most adverse circumstances, amidst the distraction of pressing official duties. I rejoice to think that many of the valuable researches have been carried on in IACS, founded by our illustrious colleague Dr. ML Sircar, who devoted a lifetime to the foundation of an institution. I should fail in my duty if were to restrain myself in my expression of the genuine admiration I feel for the courage and spirit of selfsacrifice with which Mr. Raman has decided to exchange a lucrative official appointment with attractive prospects for a university professorship, which I regret to say, does not carry even liberal emoluments. This one instance encourages me to entertain the hope that there will be no lack of seekers of truth in the Temple of Knowledge, which it is our ambition to erect."
\end{abstract}

Though Raman's salary as officer at the audit and accounts department was much higher than that of the Palit Professor, he decided to join Science College on two conditions. First, he refused to go abroad for a foreign training. Second, he refused to take regular classes. Asutosh accepted both the conditions said in senate of Calcutta University. Accepting these two conditions the Syndicate of Calcutta University noted,

“Mr. C V Raman's acceptance of the Sir TN Palit Professorship on condition that he will not be required to go out of India, recorded (pp.726, 1914).”

\footnotetext{
"Reported that Mr. C V Raman joined his appointment as Palit Professor of Physics from 2.7.17. referred to the Governing Body, concerned. Mr. Raman informed that he will not be required to take any
} 
teaching work in MA and MSc classes to the detriment of his own research work of his assisting advanced students in their research work (pp.1318, 1917).”

Asutosh appointed a bunch of young men as lecturer, who had just got their M. Sc. degree in 1915. They included S N Bose and M N Saha (joint first in mixed Mathematics), J C Ghosh and J N Mukherjee (joint first in Chemistry), and Sailendranath Ghosh ( $1^{\text {st }}$ in Physics). It was very difficult to get text books and laboratory equipment because after the World War started in 1915 import of all these items was banned temporarily. These young men started collecting books and equipment from private collection of many people.

During this, one day police came to arrest S N Ghosh, a freedom fighter. He escaped to USA. Many years later he returned to India as a teacher at B M College and Jagannath College (both in Bangladesh). Another Physics lecturer, Jatin Seth who was also a freedom fighter was arrested. D M Bose, Ghosh Professor of Physics, who went to Germany, was not allowed to come back during the World War. Thus in 1917 when the classes started there was a serious problem to teach Physics. S N Bose and M N Saha, started teaching Physics. In 1919, the translated the original papers of Einstein from German to English. This was published by the Calcutta University with a forward by P C Mahalanobis. Mahalanobis, a tripose from Cambridge got a fellowship to work with C T R Wilson for Ph.D. He came back to India for a vacation in 1915. When the first world War started he did not go back to England and joined the Presidency College as head of the Physics department. In 1917, Sir B N Seal entrusted P C Mahalanobis (1893-1972), to apply statistical analysis to reform the examination system of Calcutta University and submit a report. This is, perhaps, the first application of statistical method to university education, in the whole world.
Within a few years after joining the Science College M N Saha published his famous papers on Thermal Ionization Theory. J C Ghosh published several important papers on the theory of strong electrolytes.

\section{Indian Science Congress and OTHER ACTIVITIES}

Indian Science Congress was established in 1914 with an aim to create a broad platform encompassing all branch of science through a big meeting. Asutosh was the president of the first meeting of the Science Congress which was held from 15-17 January 1914 at the premises of the Asiatic Society and was attended by 105 scientists from different parts of India and abroad. Now-a-days the Science Congress is attended by 20,000 scientists every year.

Asutosh was elected as the president of the Asiatic Society for three terms. In 1910, he became the President of the Council of the Imperial Library (now called National Library) which is the largest public library in India. He donated his personal collection of 80,000 books to this library. In 1916, he founded the Asutosh College.

In 1916, Netaji Subhas Chandra Bose and a few other students were expelled from Presidency College for assaulting Professor E F Oaten who infuriated the Indian students by his derogatory remarks against Indians. In 1917, Subhas Bose's rustication was revoked by the intervention of Sir Asutosh. Asutosh further, arranged Netaji's admission to third year B.A. class with Honours in Philosophy at the Scottish Churches College, so that he did not have to lose a year. Mookerjee was a member of the 1917-1919 Sadler Commission, presided over by Michael Ernest Sadler, which was set up to review the state of Indian education.

The Dacca University was founded in 1921. They lured away J C Ghosh and S N Bose 
with offer of higher post. Asutosh joined as VC for the fifth term in 1921. He created the Khaira Professor post with a Rs. 5 lakh (half million) donation from the Maharaja of Khaira and appointed Saha to the post of the Khaira Professor. During this period, He brought Radhakrishnan to Calcutta.

In 1923, Asutosh refused another term of Vice Chancellor when Lord Lytton tried to impose conditions on his reappointment and returned to law. One year later, he passed away on 25 May, 1924 at Patna, Bihar soon after losing a hotly contested Hindu law inheritance case.

\section{FAMily LifE}

Asutosh married Jogomaya Devi in 1885 and they had three famous sons. The eldest son Shyama Prasad Mookerjee (1901-1953) was the youngest vice-chancellor of Calcutta University (1934-38). He founded the Bharatiya Jana Sangh Party. Another son Rama Prasad Mookerjee, was acting Chief Justice of the Calcutta High Court. Rama Prasad's son Chittatosh Mookerjee became Chief Justice of India. Asutosh's youngest son Uma Prasad was famous as a writer and Himalaya lover.

\section{RAMAN's Gratitude to Asutosh AND ML Sircar}

We will end this article quoting Raman's tribute to Asutosh and ML Sircar. After his Nobel Prize in 1930, the Mayor of Calcutta, Dr. Bidhan Chandra Roy, felicitated Raman on 26 $6^{\text {th }}$ June 1931. In his reply Raman expressed his gratitude to $\mathrm{M}$ L Sircar and Asutosh as follows,

“To two men, especially, I owe a gratitude that can never be repaid. It was Dr. Mahendra Lal Sircar, who, by founding the Indian Association for the Cultivation of Science made it possible for the scientific aspirations of my early years to continue to burning brightly. Dr. Sircar devoted a life-time of labor to the institution which he created and equipped with the hope that it would someday be utilized for the advancement of science in India. Its doors were open awaiting the arrival of some one. That arrival happened to be myself. Sircar, did not alas, live to see his aims accomplished. To another great citizen of Calcutta, the late Sir Asutosh Mookerjee, I am also under a deep debt. Sir Asutosh ventured to ask a young and unknown Government official to throw aside the preferments of office and devote himself to the pursuit of knowledge under the aegis of the Calcutta University. But for the action which Sir Asutosh took, my scientific career would long ago suffered an abrupt termination.”

\section{BiBLIOGRAPHY}

A Century, History of Indian Association for the Cultivation of Science (IACS), published by IACS.

A Diary of Sir Asutosh Mookerjee published by Asutosh Mookerjee Memorial Institute, Calcutta, 1998.

Biswas, Arun Kumar. Collected Works of Mahendralal Sircar, Eugene Lafont and the Science Movement. Asiatic Society, 2003.

Banerjee, Pramathanath, Ray, Niranjan (et.el), The Hundred Years of the University of Calcutta, Calcutta University Press, Calcutta, 1957.

Biswas, Arun Kumar. Gleaning of the Past Scientific Movement. Asiatic Society, 2001.

Palit, Chittabrata, Das Abhinandan, Asutosh Mookerjee: Mathesis of Mathematics, Readers Service, Kolkata, 2010

Radhakrishna, B P. Pramatha Nath Bose. Current Science, 72 (1997):222.

Ray, P C. Life and Experiences of a Hindu Chemist, Saibya Publications, 1902, reprinted 2002.

Sengupta, D P. Sir Asutosh Mookerjee- Educationist, leader and institution-builder. Current Science, 78 (2000):1566.

Sinha, N K. Asutosh Mookerjee - A Biographical Study, Calcutta, 1966

The Calcutta Municipal Gazette, CV Raman Birth Centenary Special Number (1988), published by Calcutta Municipal Corporation.

75 years of the Science College, Commemoration volume (1990), published by Calcutta University. 